International Section

Arch. Esp. Urol., 58, 10 (1.093-1.094), 2005

\title{
ISOLATED LOCAL RECURRENCE OF RENAL NEOPLASM WITH CAVAL INVOLVEMENT 16 YEARS AFTER RADICAL NEPHRECTOMY.
}

\author{
L. D'Arrigo', M. Pennisi', P. Pepe', A. Scolaro², A. Lomeo and F. Aragona'.
}

Division of Urology' and Vascular Surgery². Cannizzaro Hospital Catania. Italy.

Summary.- OBJECTIVE: To report a case of local recurrence 16 years after radical nephrectomy; to analyse literature data concerning, treatment and prognosis.

METHODS/RESULTS: We report a case of local recurence associated with caval trombosis who was underwent an en-bloc resection of vena cava along with pericaval lesion and caval replacement with PTFE prosthesis. The Authors reviewed and analysed literature data.

CONCLUSIONS: Local recurrence after radical nephrectomy is rare as it is reported only in $2-4 \%$ of patients. This condition is even rarer beyond 10 years especially if associated with caval trombosis.

A case of isolated local recurrence of renal cell carcinoma with caval involvement 16 years after radical nephrectomy is described herein. To the best of our knowledge, this is the first case reported in literature. This case highlights the opportunity of a periodic checkup of patients submitted to radical nephrectomy, even many years after surgery.
Keywords.- Renal cell carcinoma. Vena caval thrombus. Radical nephrectomy.

Resumen.- OBJETIVOS: Presentar un caso de recurrencia local de tumor renal 16 años después de nefrectomía radical; analizar los datos de la literatura sobre tratamiento y pronóstico.

MÉTODOS/RESULTADOS: Presentamos un caso de recurrencia local asociado con trombosis de la vena cava que fue intervenido mediante resección en bloque del tumor y la vena cava con sustitución por una prótesis PTFE.

CONCLUSIONES: La recurrencia local después de nefrectomía radical es rara, siendo comunicada entre el 2$4 \%$ de los pacientes. Esta condición es incluso más rara después de diez años, especialmente si está asociada con trombosis de la vena cava.

Se describe un caso de recurrencia local aislada de carcinoma de células renales con afectación de la cava 16 años después de nefrectomía radical. Pensamos que éste es el primer caso comunicado en la literatura. Este caso destaca la oportunidad de las revisiones periódicas de los pacientes sometidos a nefrectomía radical incluso muchos años después de cirugía.

Palabras clave: Carcinoma de células renales. Trombo en vena cava. Nefrectomía radical 


\section{CASE REPORT}

A 70 year-old woman was admitted to our hospital in September 2002 for progressive shortness of breath. The patient had a mild renal insufficiency and was treated with alpha-blockers for hypertension. Physical examination, ECG and echocardiography were normal. Sixteen years before, the patient underwent a right radical nephrectomy for an organconfined, $8 \mathrm{~cm}$ in size, renal cell carcinoma with neoplastic renal vein thrombosis. Follow-up at 10 years was supposedly negative and no further controls were performed since then.

On admission chest $X$ ray and thoracic $C T$ scan did not reveal any pulmonary lesion. Abdominal CT scan showed a retro and pericaval lesion close to the left renal vein and an intracaval solid lesion extending from iliac to hepatic vein (Figure 1). The extension of caval thrombus was confirmed by abdominal ultrasonography.

The patient underwent an en-bloc resection of vena cava along with pericaval lesion and caval replacement with PTFE prosthesis.

Histopatologic examination revealed a pericaval recurrence of renal cell carcinoma with caval wall infiltration.

Post-operative follow up was uneventful and dyspnea fully disappeared. At 24 months follow-up the patient is asymptomatic although tha caval prosthesis is partially occluded.

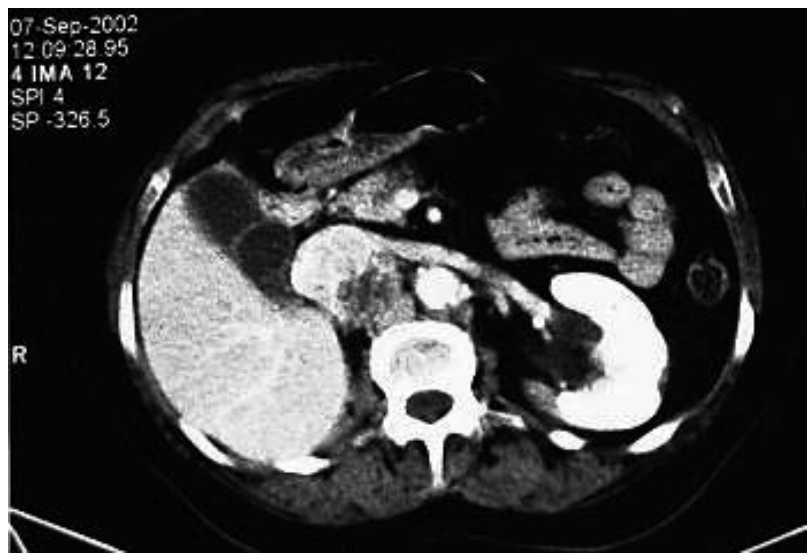

FIGURE 1. Abdominal CT Scan: A retro and pericaval lesion close to the left renal vein and an intracaval thrombus were visible.

\section{DISCUSSION}

Local recurrence after radical nephrectomy is rare as it is reported only in $2-4 \%$ of patients (1).

Caval extension occurs in $5-10 \%$ of patients with renal cell carcinoma (2). Fairly surprisingly prognosis seems not to be affected by caval involvement. Late recurrence beyond 10 years is rare, particulary if associated with caval thrombus.

From a literature review only 4 cases of solitary recurrence, occurring within 4 years after radical nephrectomy, are reported (3).

This is the only case of isolated local recurrence associated to caval involvement 16 years after surgery.

We are not in the position to explain the reason for such a late recurrece neither a literature review affronted a convincing rationale for this unusual clinical course.

This case highlights the opportunity of a periodic check-up of patients submitted to radical nephrectomy, even many years after surgery.

\section{REFERENCES AND RECOMENDED READING ("of special interest, ${ }^{* *}$ of outstanding interest)}

1. SCHRODTER, S.; HAKENBERG, O.W.; MANSECK, A. y cols.: "Outcome of surgical treatment of isolated local recurrence after radical nephrectomy for renal cell carcinoma”. J. Urol., 167: 1630, 2002.

*2. REISSIGL, A.; JANETSCHEK, G.; EBERLE, J. y cols.: "Renal Cell carcinoma extending into the vena cava: surgical approach, technique and results". Br. J. Urol., 75: 138, 1995.

**3. FINELSTEIN, M.P.; DRINIS, S.; TORTRELIS, D.G. y cols.: "Recurrence of renal cell carcinoma with extensive vena caval thrombus three years after radical nephectomy". Urol. Int., 68: 199, 2002. 